\title{
FAKTOR-FAKTOR YANG MEMPENGARUHI PENYERAPAN TENAGA KERJA PADA INDUSTRI RUMAH PANGGUNG KECAMATAN TOMPASO BARU KABUPATEN MINAHASA SELATAN
}

\author{
Jeifi Indri Liow, \\ Gene H.M. Kapantow \\ Mex L. Sondakh
}

\begin{abstract}
This study aimed to analyze the factors affecting the number of workers in the wooden house indutry at Tompaso Baru, South Minahasa. The data used were primary data obtained from the 23 available wooden house enterprises in Tompaso Baru by using questionnaires. Data were analysed using multiple regression and a Cobb Douglass Model was apllied. The Factors that were analyzed including the wages, production values and capital. The preliminary analysis shows there was a high correlation (multicollinearity) between the production value and capital. It has been decided to drop the capital factor in further analysis. Results of the analysis showed that the models used were good enough to be used for analysis, indicated by the $R^{2}$ value of $91.4 \%$ and a significant level of the model which was of less than 1\%. Partial significant level of each factor, wages and production value, was also less than $1 \%$. This showed that wages and production value were significant factors in the determining the number of workers recruited in the wooden house industry in Tompaso Baru. Both of them have positive directions, meaning that an increase in wages or production value would increase the number of workers in this industry. *ghmk*
\end{abstract}

Keywords: workers, Wooden House Industry, Tompaso Baru Sub-district, South Minahasa District

\begin{abstract}
ABSTRAK
Penelitian ini bertujuan untuk menganalisis faktor-faktor yang mempengaruhi penyerapan tenaga kerja pada industri rumah panggung kecamatan Tompaso Baru. Data yang digunakan adalah data primer yang diperoleh dari 23 pengusaha dengan menggunakan kuisioner yang telah disusun. Data analisis menggunakan analisis regresi berganda dengan menggunakan model Cobb Douglass. Faktor-faktor yang di analisis adalah upah, nilai produksi dan modal. Hasil analisis awal menunjukan ada korelasi yang tinggi (multikolinieritas) antara nilai produksi dan modal, oleh karena itu modal dikeluarkan dalam model. Hasil analisis menunjukan bahwa model yang digunakan sudah baik, ditunjukan oleh nilai $\mathrm{R}^{2}$ sebesar 91,4\% dan tingkat signifikan lebih kecil dari $1 \%$. Tingkat signifikan parsial dari masing-masing faktor yaitu upah dan nilai produksi juga lebih kecil dari $1 \%$. Ini menunjukan bahwa upah dan nilai produksi secara signifikan berpengaruh dalam penyerapan tenaga kerja pada industri rumah panggung Kecamatan Tompaso Baru sercara positif. Kenaikan upah dapat meningkatkan jumlah tenaga kerja, dan semakin tinggi nilai produksi rumah panggung dapat meningkatkan penyerapan tenaga kerja pada industri rumah panggung Kecamatan Tompaso Baru.
\end{abstract}

Kata kunci: Penyerapan Tenaga Kerja, Industri Rumah Panggung, Tompaso Baru

\section{PENDAHULUAN}

\section{Latar Belakang}

Upaya perluasan lapangan kerja merupakan suatu kebutuhan yang mendasar, sehingga perlu diambil kebijakan yang menyeluruh dan terpadu untuk memperluas kesempatan yang menyangkut pembangunan yang berorientasi pada perluasan lapangan kerja. Masalah pokok dalam pembangunan ekonomi adalah memaksimalkan penciptaan lapangan kerja secara berkelanjutan (Tjiptoherijanto, 2000 dalam Yuliarti 2006). 
Industrialisasi memiliki peran strategis untuk mendukung pertumbuhan ekonomi yang cukup tinggi secara berkelanjutan dan meningkatkan produksi fisik masyarakat melalui perluasan lapangan usaha dan memperluas kesempatan kerja, mendorong pembangunan daerah, meningkatkan dan meratakan pendapatan masyarakat serta mengentaskan masyarakat dari kemiskinan. Keberadaan Industri kecil juga memiliki kontribusi yang besar pada perkembangan perekonomian suatu daerah, karena dengan jumlah unit usaha yang banyak akan menciptakan lapangan pekerjaan serta mampu menyerap tenaga kerja sehingga berpotensi untuk mengurangi pengangguran di suatu daerah (Tambunan, 2003).

Daerah-daerah yang memiliki industri akan membawa perubahan pada masyarakat yang ada di daerah tersebut. Perubahan itu antara lain meningkatnya kegiatan sosial maupun kegiatan ekonomi yang dapat juga meningkatkan kehidupan masyarakat sekitarnya, tidak terkecuali pula jika industri tersebut adalah industri rumah panggung. Industri rumah panggung merupakan salah satu agroindustri di Sulawesi Utara, yang prospek pengembangannya tampak menjanjikan karena berbagai keunggulan yang dimilikinya, seperti harga yang relatif terjangkau oleh semua lapisan masyarakat, sistem kontruksi knock down yang memudahkan bongkar pasang, berdaya tahan lama serta cocok untuk daerah rawan gempa dan rawan banjir (Rumagit 1997 dalam Soemingkar 2014).

Terdapat beberapa sentra produksi industri rumah panggung di Sulawesi Utara, yaitu berada di Desa Woloan Kota Tomohon Kabupaten Minahasa, Desa Mokobang Kecamatan Modoinding Kabupaten Minahasa Selatan dan industri rumah panggung Kecamatan Tompaso Baru Kabupaten Minahasa Selatan. Industri rumah panggung yang berada di Kecamatan Tompaso Baru Kabupaten Minahasa Selatan, berjumlah 23 industri rumah panggung yang tersebar dibeberapa desa yaitu Desa Sion berjumlah 10, Desa Raratean berjumlah 7 dan Desa Kinalawiran berjumlah 6.

Industri rumah panggungdi Kecamatan Tompaso Baru ini adalah industri yang relatif baru, dan mulai berkembang di masyarakat dibandingkan dengan daerah lain yang sudah lebih dulu dikembangkan. Setiap sentra industri rumah panggung memiliki keunggulan tersendiri, baik jenis ataupun kualitas kayu yang digunakan. Kayu yang digunakan di Kecamatan Tompaso Baru dalam memproduksi rumah panggung adalah kayu campuran yang terdiri dari kayu cempaka dan kayu merah (Pulutan, Aras dan Benuang). Ukuran dari rumah panggung dikecamatan Tompaso Baru juga bervariasi yaitu satu kamar, dua kamar dan tiga kamar.

Agar dapat bersaing dengan sentra produksi lainnya, produksi rumah panggung di Kecamatan Tompaso Baru mempertimbangkan kualitas kayu yang digunakan, karena dengan kualitas kayu yang baik maka akan menghasilkan produksi rumah panggung yang berkualitas, selain itu harga yang relatif murah sesuai jenis kayu dan ukuran serta model produksi rumah panggung yang diproduksi. Adanya usaha industri rumah panggung di Kecamatan Tompaso Baru telah menciptakan lapangan pekerjaan,yang menyerap tenaga kerja sehingga mengurangi pengangguran di pedesaan. Setiap industri memerlukan tenaga kerja sesuai dengan jumlah produksi rumah panggung. Satu unit rumah dengan ukuran yang kecil menggunakan tenaga kerja 3 sampai 4 orang, sedangkan ukuran yang besar melibatkan 5 sampai 10 orang tenaga kerja. Dalam mengembangkan industri rumah panggung ini kendala yang dihadapi oleh pengusaha adalah modal. Modal adalah uang untuk membeli peralatan dan bahan-bahan untuk proses produksi. Modal yang banyak akan mempercepat produksinya, karena bisa membeli langsung peralatan dan bahan yang diperlukan,. Modal juga dapat mempekerjakan tenaga kerja lebih banyak, dimana tenaga kerja yang dibutuhkan tergantung pada jumlah pesanan konsumen hingga penyelesaian yang dikehendaki, jika waktu yang disepakati singkat maka diperlukan tenaga kerja lebih sehingga hal ini juga dapat mempengaruhi harga jual rumah panggung tersebut.

\section{Perumusan Masalah}

Berdasarkan latar belakang permasalahan diatas, masalah penelitian ini dapat dirumuskan sebagai berikut "Faktor-faktor apakah yang mempengaruhi penyerapan tenaga kerja pada Industri Rumah Panggung Kecamatan Tompaso Baru?" 


\section{Tujuan Penelitian}

Menganalisis faktor-faktor yang mempengaruhi penyerapan tenaga kerja pada Industri Rumah Panggung Kecamatan Tompaso Baru.

\section{Manfaat Penelitian}

1. Bagi Penulis, dapat menambah wawasan pengetahuan dalam mengaplikasikan ilmu yang telah diterima selama kuliah, melalui penelitian yang dilakukan.

2. Bagi pembaca lainnya, dapat digunakan sebagai sumber informasi untuk menambah pengetahuan dan sebagai bahan penelitian lebih lanjut bagi peneliti lainnya.

\section{METODOLOGI PENELITIAN}

\section{Waktu dan Tempat Penelitian}

Penelitian ini dilaksanakan pada bulan Februari-Juni 2016 Kecamatan Tompaso Baru Kabupaten Minahasa Selatan.

\section{Metode Pengumpulan Data}

Metode yang digunakan dalam penelitian ini adalah wawancara langsung. Data yang dikumpulkan terdiri dari data primer dan data sekunder. Data primer merupakan data penelitian yang diperoleh langsung di lapangan, mengajukan pertanyaan menggunakan kuesioner (Umar, 2003). Data sekunder adalah data yang tidak langsung memberikan data kepada peneliti, misalnya penelitian harus melalui orang lain atau mencari melalui dokumen. Data ini diperoleh dengan menggunakan studi literatur dan diperoleh berdasarkan catatan-catatan yang berhubungan dengan penelitian (Sugiyono, 2005).

Jumlah pengusaha Industri Rumah Panggung di Kecamatan Tompaso Baru berjumlah 23 orang dan sengaja dipilih sebagai responden.

\section{Konsepsi pengukuran Variabel}

1. Penyerapan tenaga kerja $(\mathrm{Y})$ adalah jumlah atau banyaknya orang yang terserap dan bekerja pada industri rumah panggung Kecamatan Tompaso Baru (Orang).

2. Upah merupakan variabel yang diukur dimana upah digunakan untuk membayar pekerja sebagai imbalan atas pekerjaan atau jasa yang telah dilakukan terhadap industri rumah panggung Kecamatan Tompaso Baru (Rp/produksi terakhir).

3. Nilai produksi merupakan variabel yang diukur dimana nilai produksi adalah nilai dari keseluruhan barang yang merupakan hasil akhir dari proses produksi pada suatu unit usaha ( $\mathrm{Rp}$ /produksi terakhir).

4. Modal merupakan variabel yang diukur dimana modal adalah keseluruhan modal uang yang digunakan untuk membeli bahan baku dan peralatan dalam produksi rumah panggung ( $\mathrm{Rp})$.

\section{Metode Analisis Data}

a. Analisis Regresi Linear Berganda

Metode analisis data ini digunakan untuk mengetahui hubungan variabel upah, nilai produksi dan modal terhadap penyerapan tenaga kerja pada Industri Rumah Panggung Kecamatan Tompaso Baru.Pola hubungan yang dipakai menggunakkan fungsi Cobb Douglass, dengan model Cobb Douglass sebagai berikut :

$$
\mathrm{Y}=\beta 0 \mathrm{X}_{1}^{\beta 1} \mathrm{X}_{2}^{\beta 2} \mathrm{X}_{3}^{\beta 3} \mu
$$

Model ini dapat dilinearkan dengan cara mentransformasikan dalam bentuk Logaritma Natural (Ln). Maka persamaan regresi linear bergandadapat dirumuskan:

$$
\operatorname{LnY}=\operatorname{Ln} \beta_{0}+\beta_{1} \operatorname{LnX} X_{1} \beta_{2} \operatorname{Ln} X_{2}+\beta_{3} \operatorname{LnX} X_{3}+\mu
$$

$$
\begin{array}{ll}
\text { Dimana: } & \\
\beta_{0} & =\text { Konstanta } \\
\beta_{1}, \beta_{2}, \beta_{3}= & \text { nilai koefisien regresi } \\
\mathrm{Y} & =\text { Jumlah tenaga kerja yang terserap } \\
& \text { (TK/Orang) } \\
\mathrm{X}_{1} & =\text { Upah (Rp) } \\
\mathrm{X}_{2} & =\text { Nilai Produksi (Rp) } \\
\mathrm{X}_{3} & =\text { Modal (Rp) } \\
\mu & = \\
& \text { Kesalahan Pengganggu yang } \\
& \text { disebabkan oleh faktor lain di luar } \\
& \text { model }
\end{array}
$$




\section{b. Uji Multikolinieritas}

Salah satu asumsi pengujian dengan regresi linear, yang sering digunakan adalah tidak adanya multikolinieritas. Uji multikolonieritas bertujuan untuk menguji apakah model regresi ditemukan adanya korelasi antar variabel bebas (independen). Model regresi yang baik seharusnya tidak terjadi korelasi diantara variabel independen. Untuk mendeteksi ada atau tidaknya multikolinieritas didalam model regresi adalah melihat nilai tolerance lebih dari 0,1 dan nilai VIF (Variance Inflation Factor) kurang dari 10 berarti tidak ada multikolinieritas. Bila ternyata dalam model regresi terdapat multikolinieritas, maka harus menghilangkan variabel yang mempunyai korelasi tinggi (Ghozali, 2009).

\section{c. Uji Koefisien Determinasi $\left(\mathrm{R}^{2}\right)$}

Koefisian determinasi (R2) pada intinya mengukur seberapa jauh kemampuan model dalam menerangkan variasi variabel dependen. Nilai koefisien determinasi adalah antara 0 dan 1. Nilai yang mendekati satu berarti variabel variabel independen memberikan hampir semua informasi yang dibutuhkan untuk memprediksi variasi variabel dependent (Ghozali, 2007).

\section{d. Uji Simultan (Uji F)}

Pengujian ini dilakukan dengan membandingkan nilai $\mathrm{F}$ hitung dengan nilai $\mathrm{F}$ tabel. Dasar pengambilan keputusan uji F :

- $\mathrm{H}_{0}$ diterima dan $\mathrm{H}_{1}$ ditolak jika probabilitas (nilai sig) $>0,05$ atau $\mathrm{F}$ hitung < F tabel.

- $\mathrm{H}_{0}$ ditolak dan $\mathrm{H}_{1}$ diterima jika probabilitas (nilai sig) $<0,05$ atau $\mathrm{F}$ hitung > F tabel.

Jika nilai $\mathrm{F}$ hitung lebih besar dari nilai $\mathrm{F}$ tabel, Ho ditolak dan $\mathrm{H}^{1}$ diterima artinya variabel bebas secara bersama-sama mempengaruhi variabel terikat

\section{e. Uji Parsial (Uji t)}

Uji t bertujuan untuk mengetahui apakah variabel bebas (X) secara parsial berpengaruh signifikan terhadap variabel terikat $(\mathrm{Y})$. Dasar pengambilan keputusan uji $\mathrm{t}$ :

- $\mathrm{H}_{0}$ diterima dan $\mathrm{H}_{1}$ ditolak jika probabilitas (nilai sig) $>0,05$ atau t hitung $<$ t tabel.
- $\mathrm{H}_{0}$ ditolak dan $\mathrm{H}_{1}$ diterima jika probabilitas (nilai sig) $<0,05$ atau t hitung $>\mathrm{t}$ tabel.

Jika nilai $\mathrm{t}$ hitung lebih besar dari nilai $\mathrm{t}$ tabel, maka Ho ditolak dan $\mathrm{H}^{1}$ diterima artinya variabel bebas (upah, nilai produksi dan modal) berpengaruh terhadap variabel terikat (penyerapan tenaga kerja).

\section{HASIL DAN PEMBAHASAN}

\section{Gambaran Umum Kecamatan Tompaso Baru}

Kecamatan Tompaso Baru adalah salah satu Kecamatan yang ada di Kabupaten Minahasa Selatan berjarak sekitar $90 \mathrm{~km}$ dari Kota Manado. Kecamatan Tompaso Baru memiliki topografi wilayah hamparan dengan ketinggian 368 meter dari permukan laut. Dengan batas wilayah terletak pada :

- Sebelah utara berbatasan dengan Kecamatan Ranoyapo

- Sebelah selatan berbatasan dengan

Kecamatan Maesaan

- Sebelah timur berbatasan dengan Kabupaten Bolaang Mongondow Timur

- Sebelah barat berbatasan dengan Kabupaten Bolaang Mongondow

Luas wilayah Kecamatan Tompaso Baru seluas 18.214,5 $\mathrm{km}^{2}$. Desa Sion, Desa Kinalawiran dan Desa Raratean merupakan Desa yang berada di Wilayah Kecamatan Tompaso Baru. Desa Sion tepatnya terletak 1 $\mathrm{km}$ dari pusat kecamatan, Desa Kinalawiran tepatnya terletak pada $1 \mathrm{~km}$ dari pusat kecamatan dan Desa Raraatean tepatnya terletak $5 \mathrm{~km}$ dari pusat kecamatan.

\section{Kependudukan}

Jumlah penduduk Kecamatan Tompaso Baru Tahun 2014, yang menjadi penelitian ini berada di Desa Raraatean berjumlah 934 jiwa dengan jumlah penduduk laki-laki 464 jiwa, perempuan 470 jiwa. Desa Sion berjumlah 1.119 jiwa dengan jumlah penduduk laki-laki 592 jiwa dan perempuan 527 jiwa. Desa Kinalawiran berjumlah 1.070 jiwa dengan jumlah penduduk laki-laki 540 jiwa dan perempuan 530 jiwa. 


\section{Karakteristik Tenaga Kerja pada Industri Rumah Panggung}

Tenaga kerja dalam penelitian ini adalah banyaknya orang yang bekerja pada industri rumah panggun Kecamatan Tompaso Baru.

Tabel 5. Jumlah Tenaga Kerja yang Bekerja pada Industri Rumah Panggung

\begin{tabular}{ccc}
\hline Jumlah & Jumlah & Persentase \\
TK & Responden & $(\%)$ \\
$3-4$ & 2 & 8,70 \\
$5-8$ & 12 & 52,17 \\
$8-11$ & 9 & 39,13 \\
Jumlah & 23 & 100 \\
\hline
\end{tabular}

Sumber : Hasil Olahan 2016

\section{Hasil Penelitian}

Upah
Upah adalah semua biaya yang dikeluarkan pengusaha industri rumah panggung di Kecamatan Tompaso Baru untuk dibayarkan kepada pekerja, dalam produksi terakhir. Upah yang dikeluarkan pengusaha pada industri rumah panggung Kecamatan Tompaso Baru meliputi upah harian.

Upah dibayar perhari kepada pekerja Industri rumah panggung, untuk upah perhari Kepala Bas adalah sebesar Rp 150.000 - Rp 175.000, sedangkan upah Kenek adalah Rp 100.000 - Rp 125.000. Upah tenaga kerja Industri Rumah Panggung Kecamatan Tompaso Baru yaitu upah seluruh yang dibayarkan dalam produksi terakhir.

Tabel 8. Upah Tenaga Kerja Industri Rumah Panggung Kecamatan Tompaso Baru (Rp/Produksi Terakhir)

\begin{tabular}{ccc}
\hline Upah (Rp) & $\begin{array}{c}\text { Jumlah } \\
\text { Responde }\end{array}$ & $(\%)$ \\
& $\mathrm{n}$ & \\
$15.000 .000-18.000 .000$ & 6 & 26,08 \\
$19.000 .000-22.000 .000$ & 9 & 39,13 \\
$23.000 .000-26.000 .000$ & 6 & 26,08 \\
$27.000 .000-30.000 .000$ & 2 & 8,70 \\
\hline Jumlah & 23 & 100 \\
\hline
\end{tabular}

Sumber : Hasil Olahan 2016
Tabel 8 menunjukkan, nilai upah yang dikeluarkan oleh pengusaha industri rumah panggung yang membayar upah antara $\mathrm{Rp}$ 15.000.000 - Rp 18.000.000 sebanyak 6 industri, pengusaha yang membayar total upah tenaga kerja Rp 19.000.000 - Rp 22.000.000 sebanyak 9 industri, pengusaha yang membayar total upah tenaga kerja Rp 23.000.000 - Rp 26.000.000 sebanyak 6 industri dan pengusaha yang telah membayar total upah tenaga kerja Rp 27.000.000 - Rp 30.000.000 sebanyak 2 industri.

\section{Nilai Produksi}

Produksi rumah panggung yang dihasikan di Kecamatan Tompaso Baru, dengan ukuran satu kamar, dua kamar, tiga kamar dan tergantung pesanan dari konsumen. Dari data primer yang diperoleh dapat di deskriptifkan sebagai berikut.

Berdasarkan Tabel 9 menunjukkan bahwa nilai produksi satu kamar adalah Rp 55.000.000 - Rp 60.000.000 pada 2 usaha industri rumah panggung dengan persentase 8,70 persen, nilai produksi dua kamar sebesar Rp 70.000.000 Rp 85.000.000 pada 12 usaha industri rumah panggung dengan persentase 52,17 persen dan nilai produksi tiga kamar sebanyak Rp 95.000.000 - Rp 115.000.000 pada 8 usaha industri rumah panggung kecamatan Tompaso Baru dengan persentase 39,13 persen.

Tabel 9.Nilai Produksi Pada Industri Rumah Panggung Kecamatan Tompaso Baru (Rp/produksi terakhir)

\begin{tabular}{ccc}
\hline Nilai Produksi (Rp) & $\begin{array}{c}\text { Jumlah } \\
\text { Responden }\end{array}$ & $(\%)$ \\
\hline $55.000 .000-60.000 .000$ & 2 & 8,70 \\
$70.000 .000-85.000 .000$ & 12 & 52,17 \\
$95.000 .000-125.000 .000$ & 9 & 39,13 \\
\hline Jumlah & 23 & 100 \\
\hline
\end{tabular}

Sumber : Hasil Olahan 2016

\section{Modal}

Modal dalam hal ini diukur berdasarkan modal keseluruhan yang dikeluarkan oleh perusahaan untuk membangun tempat produksi rumah panggung membeli bahan baku dan peralatan. Ukuran dan kapasitas perusahaan yang berbeda-beda, maka modal perusahaan pada industri rumah panggung juga berbedabeda. Dapat dilihat pada Tabel 10. 


\section{Tabel 10.Modal Pada Industri Rumah Panggung Kecamatan Tompaso Baru (Rp)}

\begin{tabular}{ccc}
\hline Modal (Rp) & $\begin{array}{c}\text { Jumlah } \\
\text { Responde } \\
\mathrm{n}\end{array}$ & $(\%)$ \\
\hline $40.000 .000-50.000 .000$ & 3 & 13,04 \\
$55.000 .000-70.000 .000$ & 11 & 47,82 \\
$75.000 .000-100.000 .000$ & 9 & 39,13 \\
\hline Jumlah & 23 & 100 \\
\hline
\end{tabular}

Sumber : Hasil Olahan 2016

Tabel 10 menunjukkan besarnya modal yang digunakan oleh pengusaha industri rumah panggung sebagian besar antara Rp 55.000.000 - Rp 70.000.000 (47,82 persen).

\section{Hasil Pengolahan Data}

\section{Analisis Regresi Linear Berganda}

Analisis data dan pengujian hipotesis dalam penelitian ini dilakukan dengan model regresi linear berganda, dimana dalam analisis regresi tersebut akan menguji pengaruh upah, modal dan nilai produksi terhadap penyerapan tenaga kerja pada industri rumah panggung Kecamatan Tompaso Baru. Variabel penelitian ditransformasikan dalam bentuk logaritma natural (Ln).

Tabel 11, menunjukkan bahwa adanya korelasi yang tinggi antara modal dan nilai produksi sehingga menyebabkan terjadinya multikolinieritas. Hasil yang diperoleh untuk variabel modal, nilai tolerance $0,057<0,1$ dan nilai VIF 17,591 > 10. Untuk variabel nilai produksi, tolerance $0,056<0,1$ dan nilai VIF 17,950 > 10. Salah satu cara untuk mengatasi multikolinieritas adalah dengan mengeluarkan salah satu variabel yang paling berkorelasi. Variabel modal menjadi variabel yang dikeluarkan karena berkorelasi tinggi.

Hasil analisis regresi linear dengan mengeluarkan satu variabel, diperoleh hasil berdasarkan Tabel 12, model regresi yang diperoleh tidak menimbulkan gejala multikolinieritas, karena nilai tolerance variabel upah dan nilai produksi $0,363>0,1$ dan nilai VIF variabel upah dan nilai produksi $2,758<10$. Hasil analisis regresi linear berganda diperoleh koefisien untuk variabel bebas $\mathrm{X} 1=0,539$ dan $\mathrm{X} 2 \mathrm{X} 2=0,973$ sehingga model persamaan regresi linear diperoleh :

$$
\begin{aligned}
& \operatorname{Ln} Y=\operatorname{Ln} \beta_{0}+\beta_{1} \operatorname{Ln} X_{1}+\beta_{2} \operatorname{Ln} X_{2}+\mu \\
& \operatorname{LnY}=-24.953+0.539 \operatorname{Ln} . X 1+0.973 \operatorname{Ln} . X 2
\end{aligned}
$$

Model persamaan regresi dalam bentuk cobb douglass adalah :

$$
\begin{aligned}
& Y=\beta 0 X_{1}{ }^{\beta 1} X_{2}{ }^{\beta 2} \mu \\
& Y=\left(1.45 \times 10^{-11}\right) X_{1}{ }^{0.539} X_{2}{ }^{0.973}
\end{aligned}
$$

Pengaruh upah terhadap penyerapan tenaga kerja pada industri rumah panggung Kecamatan Tompaso Baru, berpengaruh positif, nilai koefisien regresi yaitu 0,539 , hal ini berarti setiap ada peningkatan nilai upah (X1) sebesar 1 persen, maka penyerapan tenaga kerja (Y) akan meningkat sebesar 0,539 persen, dengan asumsi variabel nilai produksi adalah konstan.

Pengaruh nilai produksi terhadap penyerapan tenaga kerja pada industri rumah panggung Kecamatan Tompaso Baru, berpengaruh positif, nilai koefisien regresi yaitu 0,973, hal ini berarti setiap ada peningkatan nilai produksi (X2) sebesar 1 persen, maka penyerapan tenaga kerja (Y) akan meningkat sebesar 0,973 persen, dengan asumsi variabel upah adalah konstan. 
Tabel 11. Analisis Regresi Pengaruh Upah, Nilai Produksi dan Modal Terhadap Penyerapan Tenaga Kerja pada Industri Rumah Panggung Kecamatan Tompaso Baru

\begin{tabular}{cccccc}
\hline $\begin{array}{c}\text { Variabel } \\
\text { Independent }\end{array}$ & Formulasi & Koefisien Regresi & Sig & Tolerance & VIF \\
\hline Konstanta & & -20.987 & 0.000 & & \\
Upah & Ln_Upah & 0.483 & 0.001 & .356 & 2.805 \\
Nilai Produksi & Ln_NP & -198 & 0.577 & .056 & 17.950 \\
Modal & Ln_Modal & 1.021 & 0.002 & .057 & 17.591 \\
\hline
\end{tabular}

Sumber : Hasil Olahan 2016

Tabel 12. Analisis Regresi Pengaruh Upah dan Nilai Produksi Terhadap Penyerapan Tenaga Kerja pada Industri Rumah Panggung Kecamatan Tompaso Baru

\begin{tabular}{cccccc}
\hline $\begin{array}{c}\text { Variabel } \\
\text { Independent }\end{array}$ & Formulasi & Koefisien Regresi & Sig & Tolerance & VIF \\
\hline Konstanta & & & & & \\
Upah & Ln_Upah & -24.953 & 0.000 & & \\
Nilai & Ln_NP & 0.539 & 0.002 & 0.363 & 2.758 \\
Produksi & & 0.973 & 0.000 & 0.363 & 2.758 \\
\hline
\end{tabular}

Sumber : Hasil Olahan 2016

\section{Uji Koefisien Determinasi}

Analisis koefisien determinasi dilakukan untuk mengetahui seberapa besar nilai persentase kontribusi variabel bebas terhadap variabel terikat. Dari hasil perhitungan didapatkan nilai koefisien determinasi. Koefisien determinasi terletak pada tabel $R$ square. Dari hasil perhitungan statistik dapat diketahui bahwa nilai $R$ Square sebesar 0,914, hal itu berarti bahwa variabel $\mathrm{Y}$ dipengaruhi oleh perubahan X1 dan X2 sebesar 91,4 persen, sedangkan sisanya dipengaruhi variabel yang ada diluar model sebesar 8,6 persen.

\section{Pengujian Secara Simultan (Uji F)}

Hasil pengujian simultan (uji F) menunjukkan bahwa nilai Ftabel didapat dari $\mathrm{df} 1=(\mathrm{k}-1)$ atau $3-1=2, \mathrm{df} 2=(\mathrm{n}-\mathrm{k}-1)$ atau $23-$ $3-1=19$ dengan alpha $=0,05$. Diperoleh nilai Fhitung sebesar 106,399. Karena nilai Fhitung $106,399>$ Ftabel 3,52 atau besarnya probabilitas sebesar $0,000<0,05$. Dengan demikian, dalam penelitian ini menyatakan bahwa ada pengaruh yang signifikan antara upah dan nilai produksi secara bersama-sama terhadap penyerapan tenaga kerja.

\section{Pengujian Secara Parsial (Uji t)}

Hasil perhitungan statistik diperoleh nilai $\mathrm{t}$ hitung variabel upah sebesar 3,643>t tabel 1,713 dengan signifikan sebesar $0,002<0,05$, maka Ho ditolak dan $\mathrm{H}_{1}$ diterima maka menunjukan bahwa nilai $\mathrm{t}$ yang diperoleh tersebut signifikan. Sehingga nilai upah berpengaruh positif terhadap penyerapan tenaga kerja pada industri rumah panggung Kecamatan Tompaso Baru.

Hasil perhitungan statistik diperoleh nilai t hitung variabel nilai produksi sebesar 5,596 > t tabel 1,713 dengan signifikan sebesar $0,000<$ 0,05, maka Ho ditolak dan $\mathrm{H}_{1}$ diterima maka menunjukan bahwa nilai $t$ yang diperoleh tersebut signifikan secara nyata. Sehingga nilai produksi berpengaruh positif terhadap penyerapan tenaga kerja pada industri rumah panggung Kecamatan Tompaso Baru dapat.

Pembahasan 


\section{Pengaruh Upah Terhadap Penyerapan Tenaga Kerja}

Upah yang terus meningkat secara langsung akan membawa dampak positif pada penyerapan tenaga kerja, karena dengan adanya peningkatan upah tersebut para pengusaha akan berupaya untuk meningkatkan atau menambah jumlah unit usahanya sehingga dengan adanya penambahan unit usaha pengusaha secara otomatis akan menambah pula jumlah tenaga kerjanya.

Upah adalah suatu penerimaan sebagai imbalan kepada tenaga kerja atas pekerjaannya. Besar kecilnya tingkat upah akan mempengaruhi penyerapan tenaga kerja. Dari hasil analisis bahwa nilai $\beta_{1}$ menunjukkan angka sebesar 0,539 artinya setiap ada peningkatan $1 \%$ untuk upah maka akan meningkatkan penyerapan tenaga kerja sebesar 53,9 \% pada Industri Rumah Panggung Kecamatan Tompaso Baru.

Variabel tingkat upah mempunyai pengaruh yang positif dan signifikan, hal ini dapat dilihat dari analisis data bahwa t hitung untuk upah mempunyai nilai sebesar 3,643>t tabel 1,713. Dimana apabila terjadi kenaikkan tingkat upah maka penyerapan tenaga kerja akan meningkat. Hubungan positif yang terjadi ini sesuai dengan penelitian yang dilakukan Budiawan (2012), Luh Diah Citraresmi Cahyadi (2013) dan Rini Anita Sari (2015) yang menyatakan bahwa variabel upah memliki hubungan positif terhadap penyerapan tenaga kerja. Kenaikan yang terjadi akan menentukan produktivitas pekerja karena dengan naiknya upah maka akan memberikan motivasi bagi pekerja.

Upah mengalami peningkatan maka konsumsi pekerja juga akan meningkat yang pada akhirnya akan berpengaruh terhadap naiknya permintaan barang dan jasa sehingga pengusaha juga akan menambah jumlah tenaga kerja yang dibutuhkan. Hasil penelitian ini dikarenakan saat Industri Rumah Panggung di Kecamatan Tompaso Baru mempunyai permintaan pesanan yang banyak, maka pengusaha akan menambah serapan tenaga kerja untuk proses produksi rumah panggung, untuk menyerap tenaga kerja pengusaha akan berupaya menaikkan upah tenaga kerja. Setiap perusahaan menginginkan kinerja tenaga kerja yang baik, untuk mengembangkan dan meningkatkan hasil produksi, dengan meningkatkan upah maka dapat memotivasi tenaga kerja dan semangat dalam pekerjaannya.

\section{Pengaruh Nilai Produksi Terhadap Penyerapan Tenaga Kerja}

Nilai produksi adalah tingkat produksi atau jumlah barang yang merupakan hasil akhir proses produksi pada suatu unit usaha yang selanjutnya akan dijual sampai ke tangan konsumen. Dari hasi analisis bahwa $\beta_{2}$ menunjukkan angka sebesar 0,973 artinya setiap ada kenaikan $1 \%$ untuk modal maka akan meningkatkan penyerapan tenaga kerja sebesar $97,3 \%$. Variabel nilai produksi mempunyai pengaruh positif dan signifikan secara nyata terhadap penyerapan tenaga kerja, hal ini dapat dilihat dari hasil analisis data bahwa bahwa $\mathrm{t}$ hitung untuk modal sebesar 5,596> t tabel 1,713. Sehingga nilai produksi mempunyai peranan yang penting dalam menentukan penyerapan tenaga kerja pada industri rumah panggung Kecamatan Tompaso Baru.

Sesuai dengan teori Simanjuntak (2009) nilai produksi adalah tingkat produksi atau keseluruhan jumlah barang yang dihasilkan. Tinggi rendahnya jumlah tenaga kerja yang diminta oleh pengusaha dipengaruhi oleh tinggi rendahnya jumlah barang yang diproduksi oleh tenaga kerja tersebut. Tinggi tendahnya barang yang diproduksi tergantung kepada tinggi rendahnya permintaan oleh konsumen.

Semakin tinggi produksi yang dihasilkan oleh industri rumah panggung di Kecamatan Tompaso Baru, tergantung kepada permintaan oleh konsumen. Semakin tinggi jumlah barang yang diminta oleh konsumen, semakin tinggi jumlah barang yang diproduksi maka secara tidak langsung jumlah tenaga kerja yang dibutuhkan juga semakin tinggi. Sebaliknya, semakin menurun tingkat produksi, maka jumlah tenaga kerja yang dibutuhkan juga semakin sedikit.

Jumlah tenaga kerja dalam memproduksi rumah panggung di Kecamatan Tompaso Baru dengan ukuran yang kecil satu kamar, menggunakan tenaga kerja 3 sampai 4 orang, jika memproduksi rumah panggung ukuran dua sampai tiga kamar maka tenaga kerja yang 
dibutuhkan lebih banyak yaitu 5 sampai 10 orang. Penyerapan tenaga kerja signifikan secara nyata dipengaruhi oleh nilai produksi. Karena, semakin berkembangannya usaha industri rumah panggung, nilai produksi yang dihasilkan juga semakin banyak, sehingga penyerapan tenaga kerja juga meningkat.

Hasil dari uji koefisien determinasi bahwa, pengaruh dari variabel-variabel bebas dalam penelitian ini memiliki pengaruh yang besar dengan nilai $\mathrm{R}^{2}$ atau $R$ Square sebesar $91,4 \%$. Jadi, telah dibuktikan dalam penelitian ini variabel upah dan nilai produksi memiliki pengaruh yang signifikan terhadap penyerapan tenaga kerja pada industri rumah pangung Kecamatan Tompaso Baru. Secara simultan atau bersama-sama antara variabel bebas (upah dan nilai produksi) mempunyai pengaruh yang signifikan dan nyata terhadap variabel terikat (penyerapan tenaga kerja) dapat dilihat dari hasil analisis bahwa nilai Fhitung lebih besar dari F-tabel yaitu 106,399 > 3,52, hal ini menunjukkan bahwa secara bersama-sama variabel-variabel bebas mempunyai pengaruh yang signifikan terhadap penyerapan tenaga kerja pada industri rumah panggung Kecamatan Tomapaso Baru.

\section{KESIMPULAN DAN SARAN}

\section{Kesimpulan}

Hasil penelitian dapat disimpulkan bahwa, faktor-faktor yang mempengaruhi penyerapan tenaga kerja pada Industri Rumah Panggung Kecamatan Tompaso Baru adalah upah dan nilai produksi.

Variabel upah dan nilai produksi berpengaruh positif dan signifikan terhadap penyerapan tenaga kerja pada Industri Rumah Panggung Kecamatan Tompaso Baru. Kenaikan upah dapat meningkatkan jumlah tenaga kerja dan produktivitas tenaga kerja dalam meningkatkan kualitas produksi rumah panggung. Semakin tinggi nilai produksi rumah panggung dapat meningkatkan penyerapan tenaga kerja pada industri rumah panggung Kecamatan Tompaso Baru.

\section{Saran}

Bagi pengusaha, untuk meningkatkan permintaan tenaga kerja pengusaha harus meningkatkan unit usaha yang ada. Hal ini sangat membantu dalam penyerapan tenaga kerja. Pengusaha dengan tujuan memaksimumkan keuntungan sebaiknya meningkatkan harga outputnya dan meningkatkan penggunaan tenaga kerjanya. Jika harga output meningkat dan daya beli konsumen meningkat maka permintaan produk meningkat dan kegiatan produksi meningkat sehingga diperlukan penambahan tenaga kerja.

\section{DAFTAR PUSTAKA}

Amin Budiawan, 2012. Faktor-faktor Yang Mempengaruhi Penyerapan Tenaga Kerja Pada Industri Kecil Pengolahan Ikan Di Kab. Demak. Skripsi Universitas Negeri Semarang. Semarang

Anoraga, Pandji. 2002. Koperasi, Kewirausahaan, dan Usaha Kecil. Rineka Cipta. Jakarta

Arsyad, Lincolin. 2010. Ekonomi Pembangunan. Edisi Kelima. Yogyakarta: UPP STIMYKPN.

BPS Sulawesi Utara, 2015. Keadaan Ketenagakerjaan. Provinsi Sulawesi Utara.

Ghozali, Imam. 2009. Aplikasi Analisis Multivariate Dengan Program SPSS Cetakan IV. BP UNDIP. Semarang

Gujarati, Damodar. 2003. Ekonometrika Dasar : Edisi Keenam. Jakarta: Erlangga.

Heru Setiyadi, 2008. Penyerapan Tenaga Kerja Pada Industri Kecil Konveksi (Studi Kasus Desa Sendang Kecamatan. Kalinyamatan Kab. Jepara). Tesis Universitas Diponegoro Semaranag.

Kuncoro, M. 2007. Ekonomika Industri Indonesia. CV. Andi Offset. Yogyakarta

Mankiw, 2006. Pengantar Ekonomi Makro. Salemba Empat. Jakarta 
Mulyadi, S. 2003. Ekonomi Sumber Daya Manusia. PT Raja Grafindo Persada. Jakarta

Oktarinda, R. 2007. Dampak perkembangan Industri Besar Terhadap Sosial Ekonomi di Kabupaten Temanggung.Skripsi. Di akses tanggal 9 Desember 2015.

Rejekiningsih, Tri Wahyu. 2004. Mengukur Besarnya Peranan Industri Kecil dalam Perekonomian di Propinsi Jawa Tengah. Jurnal: Dinamika Pembangunan Vol. 1. No. 2. Semarang.

Riduwan, 2007. Rumus dan Data dalam Analisis Statistika. Bandung

Ritonga dan Yoga Firdaus. 2007. Tenaga Kerja, angkatan Kerja dan kesempatan Kerja. Phibeta. Jakarta

Riyanto, B, 2010. Dasar-dasar Pembelanjaan Perusahaan. Yogyakarta: BPFE

Saputri, Oktaviana D. 2011. Analisis Penyerapan Tenaga Kerja di Kota Salatiga. SKRIPSI : Universitas Diponegoro. Semarang

Sholeh, Maimun. 2007. Permintaan Dan Penawaran Tenaga Kerja Serta Upah :Teori Serta Beberapa Potretnya Di Indonesia.

Simanjuntak, Payaman J. 2009. Manajemen Hubungan Industrial. Jala Permata Aksara. Jakarta

Sitanggang, I, R, dan Nachrowi, Djalal. 2004. Pengaruh Struktur Ekonomi pada Penyerapan Tenaga Kerja Sektoral: Analisis Model demometrik di 30 Propinsi pada 9 Sektor di Indonesia. Vol. V No.1
Soemarso, 2009. Akuntansi Suatu Pengantar. Edisi Kelima. Salemba Empat. Jakarta

Soekartawi, 2002. Teori Ekonomi Produksi : Dengan Pokok Bahasan Analisis Cobb Douglass. Raja Grafindo Persada. Jakarta

Soemingkar, 2014. Analisis Finansial Industri Rumah Kayu CV Rajawali Tunggal Perkasa di Desa Woloan 1 Utara Kecamatan Tomohon Barat. Skripsi: Fakultas Pertanian Unsrat. Manado

Sugiyanto, 2002. Ekonomi Mikro. Yogyakarta: BPFE Yogyakarta.

Sugiyono, 2001. Metode Penelitian Administrasi. Alfabeta. Bandung

Sukirno, S. 2006. Mikro Ekonomi Teori Pengantar. Edisi Ketiga. Rajagrafindo Persada. Jakarta.

Tambunan, T, 2003. Perkembangan Sektor Pertanian di Indonesia: Beberapa Isu Penting. Ghalia Indonesia. Jakarta

Todaro, P Michael. 2003. Ekonomi Pembangunan Dunia Ketiga. Erlangga Jakarta.

Umar, Husein. 2003. Metode Riset Komunikasi Organisasi. PT Gramedia Pustaka Utama. Jakarta

Yuliarti, E, 2006. Analisis Pertumbuhan Kesempatan Kerja Pasca Kebijakan Upah Minimum Di Kabupaten Bogor. Skripsi: Fakultas Ekonomi Dan Manajemen Institut Pertanian Bogor. Bogor

Zamrowi, M. Taufik. 2007. Analisis Penyerapan Tenaga Kerja Pada Industri Kecil (Studi di Industri Kecil Mebel Kota Semarang). Tesis: Program Pascasarjana Universitas Diponegoro. Semarang 